\title{
Different Types of Cell Cycle- and Apoptosis- Related Gene Expressions Alter in Corticosteroid-, Vincristine-, and Melphalan-Resistant U-266 Multiple Myeloma Cell Lines
}

\author{
Hücre Döngüsü ve Apoptoz ile İlgili Gen Ífadelerinin \\ Kortikosteroid, Vinkristin ve Melfalan Dirençli U-266 Multipl \\ Myelom Hücre Hatlarında Analizi
}

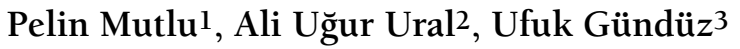

${ }^{1}$ Middle East Technical University, Central Laboratory, Molecular Biology and Biotechnology RED Center, Ankara, Turkey

${ }^{2}$ Bayindir Hospital, Clinic of Hematology, Ankara, Turkey

${ }^{3}$ Middle East Technical University, Department of Biological Sciences, Ankara, Turkey

\begin{abstract}
:
Objective: Deregulation of the cell cycle and apoptosis mechanisms in normal cells causes many problems, including cancer. In this study, a genome-wide expression analysis of cell cycle- and apoptosis-related genes in corticosteroid-, vincristine-, and melphalan-resistant U-266 multiple myeloma cell lines was conducted.

Materials and Methods: Resistant U-266 sublines were induced by application of each drug by stepwise dose increments. Resistance gained by the cells was confirmed with XTT cytotoxicity assay and microarray analyses were carried out. Among the cell cycle- and apoptosis-related gene expressions, alterations of more than 2-fold were considered significant.

Results: Cyclin E2 was drastically overexpressed in the vincristine-resistant subline and a general upregulation was observed for various cyclin-dependent kinases. Some of the cyclin-dependent kinase inhibitor encoding genes were downregulated in resistant sublines in general. Tumor necrosis factor receptor genes were generally downregulated in corticosteroid-and melphalan-resistant U-266 sublines. Different types of effector caspases were downregulated in all resistant sublines. Ceramide metabolism genes seemed to be changed in favor of survival, especially in the melphalan-resistant subline.

Conclusion: This report shows that different types of chemotherapeutic drugs alter different apoptotic and cell cycle-related gene expressions and, as a result, may cause drug-resistant phenotypes in U-266 multiple myeloma cell lines. Among those gene expressions, the most drastic increase in cyclin E2 could be important for the survival of vincristine-resistant U-266 cell lines, whereas alteration of ceramide metabolism genes could be important in melphalan resistance.
\end{abstract}

Key Words: Drug resistance, Multiple myeloma, Cell cycle, Apoptosis

Address for Correspondence: Ufuk GÜNDÜZ, M.D.,

Middle East Technical University, Department of Biological Sciences, Ankara, Turkey

Phone: +903122105183 E-mail: ufukg@metu.edu.tr

Received/Geliş tarihi : July 4, 2013

Accepted/Kabul tarihi : September 16, 2013 


\section{Özet:}

Amaç: Normal hücrelerde hücre döngüsü ve apoptoz mekanizmalarının düzensiz çalışması kanser de dahil olmak üzere pek çok soruna neden olmaktadır. Bu çalışmada; kortikosteroid, vinkristin ve melfalan'a dirençli U-266 multipl miyelom hücre hatlarında hücre döngüsü ve apoptoz ile ilgili genlerin ifade düzeylerindeki farklılıklar incelenmiştir.

Gereç ve Yöntemler: İlaç dirençli U-266 hücre hatları her bir ilacın artan dozlarda U-266 hücrelerine uygulanması ile geliştirilmiştir. Dirençlilik gelişimi XTT sitotoksisite testleri ile gösterilmiş ve mikroarray analizi gerçekleştirilmiş̧ir. Hücre döngüsü ve apoptoz ile ilgili olan gen ifadelerinden iki katın üzerinde olan değişiklikler anlamlı olarak kabul edilmiştir.

Bulgular: Vinkristin dirençli U-266 hücre hattında siklin E2 gen ifadesinin büyük ölçüde arttığı ve çeşitli siklin bağımlı kinaz genlerinin ifadelerinde genel olarak artış olduğu gözlenmiştir. Dirençli hatlarda, bazı siklin bağımlı kinaz inhibitörü kodlayan gen ifadelerinde azalma saptanmıştır. Tümör nekroz faktörü reseptör genlerinin ifadeleri kortikosteroid ve melfalan dirençli U-266 hücre hatlarında genellikle azalmıştır. Tüm dirençli hücrelerde farklı tiplerdeki efektör kaspaz gen ifadelerinde azalma gözlenmiştir. Seramid metabolizması gen ifadelerinde ise melfalan dirençli U-266 hücrelerinin hayatta kalmalarını sağlayacak şekilde değişimler saptanmıştır.

Sonuç: Bu sonuçlar, farklı kemoterapötik ilaçların farklı apoptoz ve hücre döngüsü ile ilgili gen ifadelerini değiştirerek U-266 multipl myeloma hücre hatlarında dirençliliğe neden olabileceğini göstermektedir. Bu gen ifadeleri arasında, siklin E2'deki yüksek artış vinkristine dirençli U-266 hücrelerinin hayatta kalımı için önemli olabilecekken, seramid metabolizması ile ilgili gen ifade değişiklikleri melfalan direnci açısından önemli olabileceği düşünülmektedir.

Anahtar Sözcükler: İlaç direnci, Multipl myelom, Hücre döngüsü, Apoptoz

\section{Introduction}

The emergence of drug resistance in tumor cells is a major complication for successful anticancer chemotherapy [1]. The balance between cell proliferation and apoptosis is a critical phenomenon for both development and normal tissue homeostasis. Deregulation of these processes in a normal cell results in many diseases, including cancer. Identification of genes that control cell death and apoptosis shows a linkage between apoptosis and cell cycle control mechanisms [2]. In one study it was shown that doxorubicin-resistant lung carcinoma cells exhibit altered cell cycle responses [3].

The cell cycle governs the fate of the cell [4]. Progression is controlled by external and internal signals. Cell cycle checkpoints control events throughout the cell cycle by the help of cyclins and cyclin-dependent kinases (CDKs) [4,5]. Cyclins are a family of proteins that control the progression of cells through the cell cycle by activating CDK enzymes [6,7]. At least 9 structurally related CDKs (CDK1-CDK9) have been identified. A considerable number of cyclins have also been identified to date (cyclin A-cyclin T) [4].

Cell cycle-mediated drug resistance is an important problem that must be overcome in cancer chemotherapy. It is best described as a relative insensitivity to a chemotherapeutic agent because of the position of the cells in the cell cycle. It was demonstrated when flavopiridol exposure was followed by paclitaxel in human gastric and breast cancer cells. The multiple cell cycle effects of flavopiridol, including the inhibition of different CDK activities at the G1 and G2 phases, create cell cycle arrest, which prevents cells from entering the $\mathrm{M}$ phase $[8,9]$.

The process of apoptosis is controlled by a diverse range of cell signals, either extracellularly (toxins, hormones, growth factors) or intracellularly (glucocorticoids, heat, radiation, viral infection, nutrient deprivation) $[10,11]$. There are 2 main methods of regulation for apoptosis, either targeting mitochondria functionality or directly transducing the signal via adaptor proteins to the apoptotic mechanisms. In the mitotic process, mitochondrial proteins known as small mitochondria-derived activators of caspases are released into the cytosol following an increase in permeability and then bind to inhibitor of apoptosis proteins (IAPs), preventing the IAPs from arresting the apoptosis [12]. For the direct transduction process, 2 theories have been suggested: the tumor necrosis factor-induced (TNF) model and the Fas-Fas ligand-mediated model, both involving receptors (TNFRs) coupled to extrinsic signals [13]. There is a balance between proapoptotic (bax, bid, bak, bad) and antiapoptotic (bcl-xl, bcl-2) proteins following TNF-R1 and Fas activation [14]. Caspases, which play a central role in apoptosis, are highly conserved proteases that degrade a host of intracellular proteins to carry out the cell death program.

In addition to changes in the expression levels of particular proteins that are related to cell cycle and apoptosis, multidrug-resistant (MDR) cells exhibit major alterations in their sphingolipid composition. Sphingolipids, which include ceramides and sphingosine, are essential structural components of cell membranes that also have messenger functions that regulate the proliferation, survival, and death of cells $[15,16]$. Ceramide accumulation inside the cell triggers apoptosis.

A 2- to 3-fold overexpression of glucosylceramide appears to be a rather general aspect of P-glycoproteinexpressing MDR cells. An increased turnover of ceramide to glucosylceramide may allow MDR cells to escape apoptosis, 
since ceramide plays a major role in the regulation of apoptosis [1]. Glucosylceramide synthase overexpression has been shown to enhance resistance to doxorubicin, suggesting that inhibition of ceramide metabolism or catabolism might enhance cancer chemotherapy [15].

This study demonstrates a genome-wide expression analysis of cell cycle, apoptosis, and ceramide metabolism genes in corticosteroid (U-266/Pred)-, vincristine (U-266/ Vinc)-, and melphalan (U-266/Melp)-resistant multiple myeloma cells.

\section{Materials and Methods}

\section{Cell Lines}

The human U-266 multiple myeloma cell line was obtained from Gülhane Military Medical School, Ankara, Turkey. The cells were grown in RPMI 1640 medium supplemented with $10 \%$ heat-inactivated fetal bovine serum, $1 \%$ L-glutamine, and 1\% gentamicin (Biological Industries, Beit-Haemek, Israel) and were maintained at $37{ }^{\circ} \mathrm{C}$ in a humidified air atmosphere with 5\% $\mathrm{CO}_{2}$. Corticosteroid (methyl prednisolone) (U-266/Pred)-, vincristine (U-266/ Vinc)-, and melphalan (U-266/Melp)-resistant sublines were developed from the original U-266 cells by applying each drug separately in dose increments. The XTT cell viability assay was performed for original and drug-resistant sublines with the Cell Proliferation Assay Kit (Biological Industries). The fold of resistance values of the sublines were previously reported [17].

RNA Isolation, cDNA Synthesis, and Target Preparation

RNA isolation from all cells was performed using TRI reagent (Sigma, St. Louis, MO, USA) according to the manufacturer's instructions. All RNA samples were prepared as duplicates for statistical analysis. RNA concentrations were adjusted to at least $2.5 \mu \mathrm{g} / \mu \mathrm{L}$. cRNA synthesis, target hybridization, and scanning were performed at the Ankara University Biotechnology Institute (Ankara, Turkey). cDNAs were synthesized from total RNA by One-Cycle Target Labeling Assay (Affymetrix, Santa Clara, CA, USA) according to the manufacturer's instructions. Secondstrand cDNA synthesis, biotin-labeled cRNA synthesis, and cRNA fragmentation were performed using the Affymetrix GeneChip Kit. Hybridization was conducted at $45^{\circ} \mathrm{C}$ and 60 rpm for $16 \mathrm{~h}$ in an Affymetrix Gene Chip Hybridization Oven 640 and the arrays were stained using a hybridization stain kit according to the instructions in the technical manual. Washing and staining were performed in an Affymetrix GeneChip Fluidics Station 450 with EukGE-WS2v5 fluidics script. The arrays were scanned in an Affymetrix GeneChip Scanner 3000.

\section{Data Analysis}

Affymetrix GeneChip Operating Software and GeneSpring GX 7.3.1 Software (Agilent Technologies, Inc., Santa Clara, CA, USA) were used for expression data analysis. The data were normalized by robust multichip analysis method. The gene expression levels were calculated at the level of oligonucleotide sets by using the median polish method [18] and $\log 2$ equivalents were calculated. Statistically significant data were selected by independent sample t-test $(\mathrm{p}<0.05)$ between duplicate data for resistant and original cells. The genes upregulated and downregulated more than 2-fold were considered and, by using the Kyoto Encyclopedia of Genes and Genomes pathway, grouping of data that could contribute to drug resistance was performed. Finally, the genes that encode proteins related to cell cycle and apoptosis were selected and evaluated for possible relations to drug resistance phenotype. The microarray data of this study were confirmed with the RT-PCR results of the representative genes (MDR1, MRP1, Bcl-2, LRP, and BCRP) of the MDR phenotype (unpublished data).

\section{Results}

Alterations in cell cycle- and apoptosis-related genes in drug-resistant U-266 multiple myeloma sublines are shown in Table 1. Different types of cell cycle-encoding genes and CDKs, especially CDK6 (-119-fold) and cyclin D3 (-104fold), were downregulated, whereas CDK inhibitor encoding genes (CDKN2B and CDKN2A) were upregulated in the corticosteroid-resistant U-266 cell line. However, cyclin E2 and the 2 recently identified subunits of E2F, E2F7 and E2F8, were drastically overexpressed in vincristine resistance. In melphalan resistance, some of the CDK inhibitor encoding genes (CDKN1A and CDKN1C) were downregulated.

TNF alpha-induced protein 3 (TNFAIP3) and TNF receptor superfamily member 10d (TNFRSF10) were downregulated in the U-266/Pred subline. However, TNFinducible gene 6 protein (TNFAIP6) and TNF alpha-induced protein 8 (TNFAIP8) were upregulated in vincristine resistance.

Caspase- $3,-6$, and -7 are called effector caspases, which are downstream caspases that in turn cleave other protein substrates within the cell to trigger the apoptotic processes. A general downregulation of different types of caspases was observed in drug-resistant sublines (Table 1).

The baculoviral IAP repeat-containing (BIRC) group of genes, which belongs to a family that inhibits apoptosis, was overexpressed in corticosteroid and vincristine resistance but not in the melphalan-resistant subline. The Bcl-related genes (BNIP1 and BNIP3) were upregulated in the U-266/ Vinc subline whereas they were downregulated in U-266/ Pred. The most common Bcl-2 and Bcl-XL genes of this family were not significantly altered in these sublines, as confirmed by RT-PCR and western blot analysis (data not shown). The programmed cell death-related genes (PDCD11 and PDCD4) were also upregulated in the vincristine-resistant subline and downregulated in the corticosteroid-resistant one, which is parallel to Bcl-related gene expressions. 
Table 1 also shows the altered gene expressions in ceramide metabolism. The LAGl homolog ceramide synthase 6 (LASS 6), sphingomyelin phosphodiesterase (SMPD3), and degenerative spermatocyte homolog 1 lipid desaturase (DEGS1) genes were upregulated while UDP-glucose ceramide glycosyltransferase (UGCG) and $\mathrm{N}$-acylsphingosine amidohydrolase (ASAH1) genes were downregulated in the corticosteroid-resistant subline; all of these regulations cause accumulation of ceramide inside the cells. However, the LASS 6 and SMPD1 genes were downregulated in melphalan resistance, leading to degradation to ceramide inside the cells.

\section{Discussion}

The cyclin E2 gene was 487-fold overexpressed in the $\mathrm{U}-266 /$ Vinc subline. Cyclin $\mathrm{E}$ is a member of the cyclin family, which is required for the transition from the Gl to the $S$ phase [19]. On the other hand, 2 of the transcription factor E2F subunits, E2F7 and E2F8, were highly overexpressed in the vincristine-resistant U-266 subline. E2F7 and E2F8 have an important role in DNA damage response. They repress E2F site-dependent transcription in a pRb-independent manner and delay cell cycle progression. High levels of E2F7 and E2F8 expression were shown as intrinsically lower sensitivity to E2F1-dependent apoptosis [20]. In order to overcome the mitotic inhibition of vincristine, the cells seem to upregulate the expression of their cell cycle-related genes. The breast cancer type 2 susceptibility (BRCA2) and CDKN1A interacting protein is also known as BCCIP. This gene product was isolated on the basis of its interaction with BRCA2 and p21 proteins. Functional studies indicate that this protein may be an important cofactor for BRCA2 in tumor suppression and a modulator of CDK2 kinase activity via p21 [21]. p21 is an important tumor suppressor protein that is regulated by $\mathrm{p} 53$. BCCIP gene expression was downregulated in both the corticosteroid- and vincristineresistant U-266 sublines. Therefore, this downregulation may have a significant effect on cell cycle stimulation. In melphalan resistance, CDK inhibitor encoding genes (CDKN1A and CDKN1C) were downregulated, which may again be correlated with cell proliferation.

TNF acts via the TNF receptor (TNF-R) and is part of the extrinsic pathway for triggering apoptosis [13]. TNFRSF10, which is a proapoptotic gene, was shown to be upregulated in melanoma cells destined to undergo apoptosis [22]. In this study, this gene was downregulated in the corticosteroid-resistant U-266 subline, indicating a change towards cell survival. TNFAIP8 and TNFAIP6 (TSG6) genes were both upregulated in vincristine resistance. TNFAIP8 is known as an antiapoptotic protein, and TSG6 is involved in the context of inflammation and is often associated with extracellular matrix remodeling [23]. TSG-6 is a secretory protein that has been identified as a member of the hyaluronate binding protein family [24]. It binds extracellular matrix glycosaminoglycan hyaluronan [25]. It was also reported that TSG-6 modulates the interaction of hyaluronan with CD44 marker and thus can interfere with CD44-mediated interactions of lymphoid cells with hyaluronan in postcapillary venules [26]. CD44 is involved in various cell adhesion events, including lymphocyte migration, hematopoiesis, and tumor metastasis [27]. TNFRSF19, which activates the JNK signaling pathway and is capable of inducing apoptosis by a caspase-independent mechanism [28], was downregulated in the U-266/Melp subline. From these results, it can be seen that resistant sublines tend to escape apoptosis by regulating different types of TNF-related genes. Although different drugs trigger different regulatory pathways, they all tend to maintain the survival of the cell.

Different types of the effector caspases that trigger the apoptotic processes were downregulated in all resistant U-266 sublines. BIRC-related genes were overexpressed in corticosteroid- and vincristine-resistant sublines. The BIRC group of genes inhibits apoptosis by binding to TNF receptorassociated factors TRAF-1 and TRAF-2 [29]. BAG and BNIP are Bcl-related genes. These genes were upregulated in the vincristine-resistant U-266 subline and downregulated in the corticosteroid-resistant one. BAG is a Bcl-2-associated multifunctional prosurvival molecule that binds to Hsp70/ Hsc70 proteins. BNIP proteins, on the other hand, have roles in apoptosis in regulating the expression of genes associated with cell apoptosis, growth inhibition, and cell proliferation [30]. Programmed cell death is death of a cell mediated by an intracellular program. The PDCD11, PDCD4, and PDCD2 genes were overexpressed in the U-266/Vinc subline but downregulated in corticosteroid resistance, as in the case of Bcl-related genes. PDCD11 is an NFKB binding protein that colocalizes in the nucleus [31]. The PDCD4 gene encodes a protein localized to the nucleus in proliferating cells. It has recently been demonstrated to be a new tumor suppressor gene involved in colon carcinogenesis [32]. Its role in resistance of multiple myeloma cells is not clear. The PDCD2 gene encodes a nuclear protein expressed in a variety of tissues. Expression of this gene has been shown to be repressed by Bcl-6, suggesting that Bcl-6 regulates apoptosis by its effects on PDCD2 [33].

Ceramides are a family of lipid molecules. The most wellknown functions of ceramides as cellular signals include regulating the differentiation, proliferation, programmed cell death, and apoptosis of cells [34]. Increased intercellular ceramide levels are associated with apoptosis and so downregulation of genes that are responsible for ceramide synthesis or upregulation of genes that have roles in ceramide clearance is effective in cell proliferation. Constitutive degradation of sphingolipids and glycosphingolipids takes place in the acidic subcellular compartments, the late endosomes and the lysosomes. Ceramide can be further hydrolyzed by acid ceramidase to form sphingosine and a 
Table 1. Expression levels of cell cycle- and apoptosis-related genes in corticosteroid-, vincristine-, and melphalan-resistant U-266 cell lines.

\begin{tabular}{|c|c|c|c|c|c|}
\hline Gene name & $\begin{array}{l}\text { Gene } \\
\text { symbol }\end{array}$ & Description & $\begin{array}{l}\text { U-266/Pred } \\
\text { fold change }\end{array}$ & $\begin{array}{l}\text { U-266/Vinc } \\
\text { fold change }\end{array}$ & $\begin{array}{l}\text { U-266/Melp } \\
\text { fold change }\end{array}$ \\
\hline 236313_at & CDKN2B & $\begin{array}{l}\text { Cyclin-dependent kinase inhibitor } \\
\text { 2B (p15, inhibits CDK4) }\end{array}$ & +5.31 & -6.40 & NS \\
\hline 2188264_at & BCCIP & $\begin{array}{l}\text { BRCA2 and CDKN1A interacting } \\
\text { protein }\end{array}$ & -2.86 & -3.16 & NS \\
\hline 224847_at & CDK6 & Cyclin-dependent kinase 6 & -119.5 & NS & NS \\
\hline 209644_x_at & CDKN2A & $\begin{array}{l}\text { Cyclin-dependent kinase inhibitor } \\
\text { 2A }\end{array}$ & +2.56 & NS & NS \\
\hline 203469_s_at & CDK10 & Cyclin-dependent kinase 10 & -2.60 & +2.36 & NS \\
\hline 212897_at & CDC2L6 & Cell division cycle 2-like 6 & +2.53 & -2.12 & NS \\
\hline 226396_at & CDK3 & Cyclin-dependent kinase 3 & -3.13 & +3.86 & NS \\
\hline 201700_at & CCND3 & Cyclin D3 & -104 & NS & NS \\
\hline 211792_s_at & CDKN2C & $\begin{array}{l}\text { Cyclin-dependent kinase inhibitor } \\
\text { 2C (p18, inhibits CDK4 }\end{array}$ & NS & +3.81 & NS \\
\hline 203252_at & CDK2AP2 & CDK2-associated protein 2 & NS & -5.16 & NS \\
\hline 202284_s_at & CDKN1A & $\begin{array}{l}\text { Cyclin-dependent kinase inhibitor } \\
\text { 1A (p21, Cip1) }\end{array}$ & NS & -158.6 & -12.04 \\
\hline 202246_s_at & CDK4 & Cyclin-dependent kinase 4 & NS & +2.84 & NS \\
\hline 203418_at & CCNA2 & Cyclin A2 & NS & +4.25 & NS \\
\hline 205034_at & CCNE2 & Cyclin E2 & NS & +488 & NS \\
\hline 228033_at & E2F7 & E2F transcription factor 7 & NS & +177 & NS \\
\hline 219990_at & E2F8 & E2F transcription factor 8 & NS & +49 & NS \\
\hline 216894_x_at & CDKNIC & $\begin{array}{l}\text { Cyclin-dependent kinase inhibitor } \\
\text { 1C (p57, Kip2) }\end{array}$ & NS & NS & -2.88 \\
\hline 202643_s_at & TNFAIP3 & $\begin{array}{l}\text { Tumor necrosis factor, alpha- } \\
\text { induced protein } 3\end{array}$ & -4.50 & NS & NS \\
\hline 227345_at & TNFRSF 10 & $\begin{array}{l}\text { Tumor necrosis factor receptor } \\
\text { superfamily member 10d }\end{array}$ & -2.02 & NS & +2.04 \\
\hline 224090_s_at & TNFRSF19 & $\begin{array}{l}\text { Tumor necrosis factor receptor } \\
\text { superfamily member } 19\end{array}$ & NS & NS & -2.12 \\
\hline 206026_s_at & TNFAIP6 & $\begin{array}{l}\text { Tumor necrosis factor, alpha- } \\
\text { induced protein } 6\end{array}$ & NS & +5.31 & NS \\
\hline 208296_x_at & TNFAIP8 & $\begin{array}{l}\text { Tumor necrosis factor, alpha- } \\
\text { induced protein } 8\end{array}$ & NS & +2.62 & NS \\
\hline 202763_at & CASP3 & $\begin{array}{l}\text { Caspase } 3 \text {, apoptosis-related } \\
\text { cysteine peptidase }\end{array}$ & -3.38 & NS & -2.86 \\
\hline 209790_s_at & CASP6 & $\begin{array}{l}\text { Caspase } 6 \text {, apoptosis-related } \\
\text { cysteine peptidase }\end{array}$ & -8.33 & NS & NS \\
\hline
\end{tabular}




\begin{tabular}{|c|c|c|c|c|c|}
\hline 207181_s_at & CASP7 & $\begin{array}{l}\text { Caspase } 7 \text {, apoptosis-related cysteine pep- } \\
\text { tidase }\end{array}$ & NS & -3.27 & NS \\
\hline 210538_s_at & BIRC3 & Baculoviral IAP repeat-containing 3 & +404 & NS & NS \\
\hline 202076_at & BIRC2 & Baculoviral IAP repeat-containing 2 & +548 & NS & NS \\
\hline 225858_s_at & BIRC4 & Baculoviral IAP repeat-containing 4 & NS & +6.54 & NS \\
\hline 217911_s_at & BAG3 & BCL2-associated athanogene 3 & -9.31 & NS & NS \\
\hline 37226_at & BNIP1 & $\begin{array}{l}\text { BCL2/adenovirus E1B } 19 \mathrm{kDa} \text { interacting } \\
\text { protein } 1\end{array}$ & -2.98 & +2.60 & NS \\
\hline 201849_at & BNIP3 & $\begin{array}{l}\text { BCL2/adenovirus E1B } 19 \mathrm{kDa} \text { interacting } \\
\text { protein } 3\end{array}$ & -2.69 & +3.05 & NS \\
\hline 212422_at & PDCD11 & Programmed cell death 11 & -3.48 & +2.31 & NS \\
\hline 212593_s_at & PDCD4 & Programmed cell death 4 & -3.50 & +6.02 & NS \\
\hline 228420_at & PDCD2 & Programmed cell death 2 & NS & +2.51 & NS \\
\hline 212442_s_at & LASS6 & LAG1 homolog, ceramide synthase 6 & +2.08 & +2.12 & -2.18 \\
\hline 209857_s_at & SPHK2 & Sphingosine kinase 2 & +2.88 & +3.86 & NS \\
\hline 221765_at & UGCG & UDP-glucose ceramide glycosyltransferase & -18.63 & NS & NS \\
\hline 209420_s_at & SMPD1 & Sphingomyelin phosphodiesterase 1 & NS & NS & -3.45 \\
\hline 219695_at & SMPD3 & Sphingomyelin phosphodiesterase 3 & +5.65 & NS & NS \\
\hline 207431_s_at & DEGS1 & $\begin{array}{l}\text { Degenerative spermatocyte homolog } 1 \text {, } \\
\text { lipid desaturase }\end{array}$ & +2.88 & -6.14 & NS \\
\hline 213702_x_at & ASAHl & $\begin{array}{l}\mathrm{N} \text {-acylsphingosine amidohydrolase (acid } \\
\text { ceramidase) }\end{array}$ & -2.39 & -2.39 & NS \\
\hline
\end{tabular}

NS: nonsignificant.

free fatty acid, both of which are able to leave the lysosome, in contrast to ceramide. In this study, LASS 6 and SMPD1 genes were downregulated in melphalan resistance, leading to degradation to ceramide inside the cells. On the other hand, the LASS 6, SMPD3, and DEGS1 genes were upregulated while UGCG and ASAH1 were downregulated in the corticosteroid-resistant subline. These regulations cause accumulation of ceramide inside corticosteroid-resistant cells. The upregulation of ceramidase, sphingosine kinase, and glucosylceramide synthase and the downregulation of ceramide synthase genes can be important for drug resistance phenotypes since they lower the ceramide levels within the cell. In the literature, there are some studies that support this hypothesis [15]. Glucosylceramide synthase overexpression has been shown to enhance resistance to doxorubicin and alterations of ceramide/sphingosine 1-phosphate were shown to be involved in the regulation of resistance to imatinib in the K562 chronic myeloid leukemia cell line [35]. Several anticancer agents, including the cytotoxic retinoid fenretinide (4-HPR), have been shown to act by increasing tumor cell ceramide via de novo synthesis [15]. Expression of glucosylceramide synthase mRNA in the vincristine-resistant KBV200 cell line was shown in association with multidrug resistance [36].

In conclusion, in the vincristine-resistant U-266 multiple myeloma cell line, cyclin E2 gene expression was drastically increased, whereas ceramide metabolism genes were altered only in melphalan resistance in favor of survival in the U-266 cell line. However, TNF receptor genes were generally downregulated in corticosteroidand melphalan-resistant U-266 sublines. This shows that different types of chemotherapeutic drugs alter different apoptotic and cell cycle-related gene expressions. On the other hand, all of the anticancer agents studied here are currently used in the clinical treatment of multiple myeloma. In vitro, different drug-resistant U-266 multiple myeloma cell lines show altered patterns of gene expressions related to apoptosis and the cell cycle. From a clinical perspective, this in vitro study may be a guide to clinicians for the development of new treatment strategies in drug-resistant cases. In the clinical setting, patients give different responses to the same antimyeloma regimens. By figuring out the patient profile, like in the case of our in vitro study, different types of drug combinations can be 
used in order to overcome the drug resistance phenotype. However, the results of this study only provide preliminary insight into this phenomenon.

\section{Acknowledgments}

We gratefully acknowledge the Ankara University Biotechnology Research Center for technical assistance. This study was supported by TÜBİTAK (SBAG 3297), Turkey.

\section{Conflict of Interest Statement}

The authors of this paper have no conflicts of interest, including specific financial interests, relationships, and/ or affiliations relevant to the subject matter or materials included.

\section{References}

1. Klappe K, Hinrichs JW, Kroesen BJ, Sietsma H, Kok JW. MRP1 and glucosylceramide are coordinately overexpressed and enriched in rafts during multidrug resistance acquisition in colon cancer cells. Int J Cancer 2004;110:511-522.

2. Fotedar R, Diederich L, Fotedar A. Apoptosis and the cell cycle. Prog Cell Cycle Res 1996;2:147-163.

3. O'Loughlin C, Heenan M, Coyle R, Clynes M. Altered cell cycle response of drug-resistant lung carcinoma cells to doxorubicin. Eur J Cancer 2000; 36:1149-1160.

4. Kaldis P, Russo AA, Chou HS, Pavletich NP, Solomon MJ. Human and yeast cdk-activating kinases (CAKs) display distinct substrate specificities. Mol Biol Cell 1998;9:25452560 .

5. Liebermann DA, Hoffman B, Steinman RA. Molecular controls of growth arrest and apoptosis: p53-dependent and independent pathways. Oncogene 1995;11:199-210.

6. Galderisi U, Jori FP, Giordano A. Cell cycle regulation and neural differentiation. Oncogene 2003;22:5208-5219.

7. Clute P, Pines J. Temporal and spatial control of cyclin B1 destruction in metaphase. Nat Cell Biol 1999;1:82-87.

8. Motwani M, Delohery TM, Schwartz GK. Sequential dependent enhancement of caspase activation and apoptosis by flavopiridol on paclitaxel-treated human gastric and breast cancer cells. Clin Cancer Res 1999;5:1876-1883.

9. Chan TA, Hwang PM, Hermeking J, Kinzler KW, Vogelstein B. Cooperative effects of genes controlling the G2/M checkpoint. Genes Dev 2000;14:1584-1588.

10. Popov SG, Villasmil R, Bernardi J. Lethal toxin of Bacillus anthracis causes apoptosis of macrophages. Biochem Biophys Res Commun 2002;293:349-355.

11. Mattson MP, Chan SL. Calcium orchestrates apoptosis. Nat Cell Biol 2003;5:1041-1043.

12. Fesik SW, Shi Y. Controlling the caspases. Science 2001;294:1477-1478.

13. Wajant $H$. The Fas signaling pathway: more than a paradigm. Science 2002;296:1635-1636.
14. Murphy KM, Ranganathan V, Farnsworth ML, Kavallaris M, Lock RB. Bcl-2 inhibits Bax translocation from cytosol to mitochondria during drug-induced apoptosis of human tumor cells. Cell Death Differ 2000;7:102-111.

15. Reynolds CP, Maurer BJ, Kolesnick RN. Ceramide synthesis and metabolism as a target for cancer therapy. Cancer Lett 2004;206:169-180.

16. Bartke N, Hannun YA. Bioactive sphingolipids: metabolism and function. J Lipid Res 2009;50:S91-S96.

17. Mutlu P, Baran Y, Ural AU, Avcu F, Dirican B, Beyzadeoglu M, Gunduz U. Effect of cobalt-60 ( $\gamma$ radiation) on multidrugresistant multiple myeloma cell lines. Cell Biol Int 2011;35:721-725.

18. Humphries MJ. Integrin structure. Biochem Soc T 2000;28:311-339.

19. Lindahl T, Landberg G, Ahlgren J, Nordgren H, Norberg T, Klaar S, Holmberg L, Berg J. Overexpression of cyclin E protein is associated with specific mutation types in p53 gene and poor survival in human breast cancer. Carcinogesis 2004:25:375-380.

20. Zalmas LP, Zhao X, Graham AL, Fisher R, Reilly C, Coutts AS, La Thangue NB. DNA-damage response control of E2F7 and E2F8. EMBO Rep 2008;9:252-259.

21. Coleman RA, Rao P, Fogelsong RJ, Bardes ES. 2-Bromopalmitoyl-CoA and 2-bromopalmitate: promiscuous inhibitors of membrane-bound enzymes. Biochim Biophys Acta 1992;1125:203-209.

22. Kokkinakis DM, Brickner AG, Kirkwood JM, Liu X, Goldwasser JE, Kastrama A, Sander C, Bocangel D, Chada S. Mitotic arrest, apoptosis and sensitization to chemotherapy of melanomas by methionine deprivation stress. Mol Cancer Res 2006;4:575-589.

23. Ewing RW, Chu P, Elisma F, Li H, Taylor P, Climie S, McBroom-Cerajewski L, Robinson MD, O'Connor L, Li M, Taylor R, Dharsee M, Ho Y, Heilbut A, Moore L, Zhang S, Ornatsky O, Bukhman YV, Ethier M, Sheng Y, Vasilescu J, Abu-Farha M, Lambert JP, Duewel HS, Stewart II, Kuehl B, Hogue K, Colwill K, Gladwish K, Muskat B, Kinach R, Adams SL, Moran MF, Morin GB, Topaloglou T, Figeys D. Large-scale mapping of human protein-protein interactions by mass-spectrometry. Mol Syst Biol 2007;3:89.

24. Lee TH, Wisniewski HG, Vilcek J. A novel secretory tumor necrosis factor-inducible protein (TSG-6) is a member of the family of hyaluronate binding proteins, closely related to the adhesion receptor CD44. J Cell Biol 1992;116:545557.

25. Parkar AA, Day AJ. Overlapping sites on the Link module of human TSG-6 mediate binding to hyaluronan and chondroitin-4-sulphate. FEBS Letters 1997;410:413-417.

26. Lesley J, Gal I, Mahoney DJ, Cordell MR, Rugg MS, Hyman R, Day AJ, Mikecz K. TSG-6 modulates the interaction between hyaluronan and cell surface CD44. J Biol Chem 2004;279:25745-25754. 
27. Lesley J, Hyman R, Kincade PW. CD44 and its interaction with extracellular matrix. Adv Immunol 1993;54:271-335.

28. Chaudhary D, Long AJ, Bourque K, Adams D, Hubscher S, Towler P, Potts D, Wood CR. TRADE, a novel TNF receptor superfamily member, induces apoptosis and activates NFKB and Jnk. Scand J Immunol 2000;51(Suppl 1):33.

29. Rothe M, Pan MG, Henzel WJ, Ayres TM, Goeddel DV. The TNFR2-TRAF signaling complex contains two novel proteins related to baculoviral inhibitor of apoptosis proteins. Cell 1996;83:1243-1252.

30. Xie L, Qin WX, He XH, Shu HQ, Yao GF, Wan DF, Gu JR. Differential gene expression in human hepatocellular carcinoma Hep3B cells induced by apoptosis-related gene BNIP-2. World J Gastroenterol 2004;10:1286-1291.

31. Turner AJ, Knox AA, Prieto JL, McStay B, Watkins NJ. A novel small-subunit processome assembly intermediate that contains the U3 snoRNP, nucleolin, RRP5 and DBP4. Mol Cell Biol 2009;29:3007-3017.

32. Fassan M, Pizzi M, Giacomelli L, Mescoli C, Ludwig K, Pucciarelli S, Rugge M. PDCD4 nuclear loss inversely correlates with miR-21 levels in colon carcinogenesis. Virchows Arch 2011;458:413-419.
33. Baron BW, Hyjek E, Gladstone B, Thirman MJ, Baron JM. PDCD2, a protein whose expression is repressed by BCL6, induces apoptosis in human cells by activation of the caspase cascade. Blood Cells Mol Dis 2010;45:169-175.

34. Haimovitz-Friedman A, Kan CC, Ehleiter D, Persaud RS, McLoughlin M, Fuks Z, Kolesnick RN. Ionizing radiation acts on cellular membranes to generate ceramide and initiate apoptosis. J Exp Med 1994;180:525-535.

35. Baran Y, Salas A, Senkal CE, Gunduz U, Bielawski J, Obeid LM, Ogretmen B. Alterations of ceramide/sphingosine 1-phosphate rheostat involved in the regulation of resistance to imatinib-induced apoptosis in K562 human chronic myeloid leukemia cells. J Biol Chem 2007;282:1092210934.

36. Yang Q, Zhang J, Wang SM, Zhang JR. Expression of glucosylceramide synthase mRNA in vincristine-resistant KBV200 cell line in association with multidrug resistance. Di Yi Jun Yi Da Xue Xue Bao 2004;24:779-781. 